\title{
DRUMMOND E A VANGUARDA DO PRATA O RE-INVENCIONISMO
}

\author{
Joaquín Correa \\ UFSC / CAPES
}

RESUMO: Acompanhando o Manifesto Invencionista do grupo Arte Concreto Invención argentino, Carlos Drummond de Andrade (re)publicou no número 9, de março de 1947, da revista Joaquim, 0 seu texto "Invencionismo", previamente publicado no Correio da Manhã, em dezembro de 1946. Um Drummond sumamente informado descreveu, ali, o movimento e fez uma série de críticas. Esse texto, agora, é lido dentro do que aqui chamamos de "constelação Arturo", as numerosas e várias derivas do grupo que, em 1944, lançou a revista Arturo, em Buenos Aires, e definiu a vanguarda não figurativa, abstrata, concreta ou invencionista no Prata. A variante drummondiana ao projeto seria colocada ali mesmo, na revista Joaquim, e em outra revista contemporânea dela, a revista Anhembi: 0 re-invencionismo ou a escrita do retorno, onde repetição e memória se cruzam para deixar ver 0 surgimento das possibilidades que a poeira da história foi deixando quase imperceptível nos seus vestígios.

PALAVRAS-CHAVE: Carlos Drummond de Andrade; Arturo; Invencionismo.

\section{DRUMMOND AND THE PLATA'S AVANT-GARDE THE RE-INVENCIONISM}

ABSTRACT: Accompanying the Argentinian Arte Concreto Invención group and its Manifesto Invencionista, Carlos Drummond de Andrade (re)published, in the 9th number of the Joaquim magazine, in 1947, the text "Invencionismo", previously published in Correio da Manhã, in December 1946. A highly informed Drummond described the movement there and made a number of criticisms. This text is read here in what we call the "Arturo constellation", the numerous and various derivations of the group that, in 1944, launched the Arturo magazine in Buenos Aires, and defined the non-figurative, abstract, concrete, or inventionism in the La Plata River. The Drummondian variant of the project would be placed in Joaquim magazine and in another contemporary magazine, Anhembi magazine: reinvention or writing of the return, where repetition and memory are intersected to reveal the dust of history was leaving almost imperceptible in its vestiges.

KEYWORDS: Carlos Drummond de Andrade; Arturo; Inventionism.

Joaquín Correa é doutorando do Programa de Pós-Graduação em Literatura na Universidade Federal de Santa Catarina. 


\title{
DRUMMOND E A VANGUARDA DO PRATA \\ O RE-INVENCIONISMO
}

Joaquín Correa

\author{
Mas para mim os mais infelizes do mundo \\ são os que nascem duvidando si são turcos ou gregos... \\ franceses ou alemães? \\ Nem se sabe a quem perten- \\ ce a ilha de Martim Garcia!... \\ HISTORIA UNIVERSAL EM PEQUENAS SENSAÇÕES \\ Terras-de-Ninguem!... ${ }^{1}$
}

Isso se perguntava, entre uma série de exclamações, Mario de Andrade no seu "Poema Abulico", datado em dezembro de 1922 e publicado no último número da revista Klaxon, o número 8-9 de dezembro de 1922 e janeiro de 1923. A situação de entre-lugar ou, quanto menos, de difícil certificação de uma identidade fixa dessa ilha que fora ocupada e disputada, sucessivamente, por charruas e guaranis, por espanhóis, portugueses e franceses, por argentinos, uruguaios e brasileiros, e que serviu, depois, como base militar, cárcere, lazareto e lugar de desterro e onde Sarmiento pensou fundar a sua Argirópolis, pode nos ser de utilidade para imaginar as derivas da constelação Arturo, a vanguarda concreta, não figurativa ou invencionista do Prata além do Prata, no Brasil e para, em última instância, poder nos deter nesse lugar onde a poética drummondiana excede a representação e devem figura.

ARTURO Revista de Artes Abstractas, como foi seu nome completo, teve um único número lançado no verão de 1944 em Buenos Aires. Reunindo em uma constelação até esse momento inédita poemas, reproduções de pinturas e esculturas e textos críticos ou teóricos buscava-se dar fundamento a um enunciado básico: presentar e não representar. A invenção artística devia se transformar em um fato material, tanto no sentido do materialismo histórico marxista quanto no sentido fático das assim chamadas ciências duras e experimentais. A aplicação desse princípio significaria, quase que imediatamente, não só a expulsão de vários dos seus integrantes do Partido Comunista, no qual estavam filhados naquele momento, mas também a ruptura do movimento em 1946 em duas vertentes: Arte-Concreto Invención e Arte MADI.

${ }_{1}^{1}$ ANDRADE, Mario de. Poema Abúlico. Klaxon, n. 8-9, p. 15, dez. 1922 - jan. 1923. 
Além disso, a participação (e o posterior afastamento, junto com o seu irmão, Tomás Maldonado) em Arturo de Edgar Bayley foi decisiva para a criação, alguns anos depois, de Poesía Buenos Aires, revista de grande importância na definição das poéticas de um extenso período na Argentina.

Como se de um silogismo lógico se tratasse, a segunda página da Arturo apresentava as definições do dicionário de "inventar" e "invención", as duas fortemente vinculadas ao "hallazgo", que funcionariam como as premissas da decidida e negativa conclusão: "INVENCIÓN contra AUTOMATISMO": ${ }^{2}$

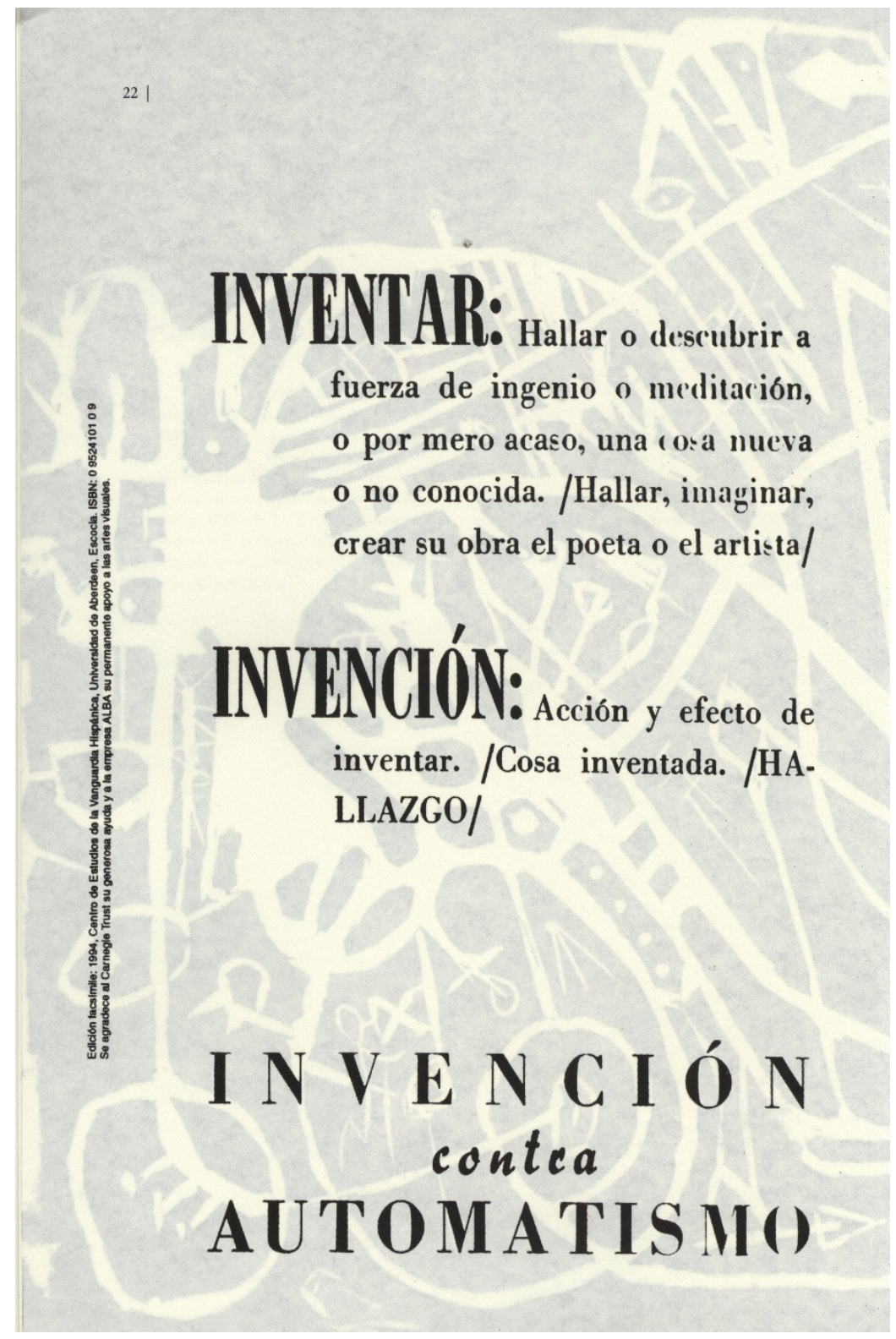

Figura 1 - Segunda página da revista Arturo, Buenos Aires, 1944

${ }^{2}$ ARDÉN QUIN, Camilo. INVENCIÓN contra AUTOMATISMO. Arturo. Edição fac-similar. Buenos Aires: Biblioteca Nacional, 2014 [n. 1, out. 1947], p. 22. 


\section{N V}

$\mathrm{M}$ AIs uma demonstração de que contlguidade territori al nem sempre é fator de conhecimento mutuo, e que a distancla intelectual nāo corresp̃onde à distancia física, está na existẻn. cla de um movimento estético que há quatro anos se desenvolve na Argentina, e de que atè agora nāo se aperceberam os melos inte. lectuais krasileiros. Jornais revistas chegados do país vizinho falam dessa nova fórmula de literatura e arte, em elaboraçao a ciois passos de nós mas a noticia morre sem éco, ao passo que ocorrências do mesmo gènero verificados na Europa, contiuuain a impressionar-nos, como o existsncialismo, que por siual é apenas uma velha noticia servida a paladares cansados ou inexperientes.

A "idéia nova" de Buenos Ai. res apresenta-se naturalmente sob a forma de "ismo", pois outra não há para definir as tentativas que ao lengo do tempo fazem as geraçōes mais jovens. no afā de desvendar o mistério estítico e exprimi-lo em termos originais (as geraçōes menos jovens reriunciam placidamente ao esfórço e nutrem-se de velhas verdades): " $t 0$ invencionismo que já produziu manifestos, exposiçoes de arte, alguns "cader. ncs" uma revista: "Arturo", compcsiçōes musicals. Como toda escola que se preza, tem os teóricos, os seus opositores e os seus heréticos. Assim, do grupo invencionista oficial já se destaccu uma fraçāo - mas isso será dito mais adiante.

Iniciou-se o movimento inven cionista em fins de 1943, com Carmelo Ardén Quin, Tomás Maldonado, Gyula Kosice, Rhod Rethfuss e-sdgard Bayley, todos mocecs. A plincipio, e isto c pecullar à pesquisa estética nāo sabiam muito tem o que queriam. Mas desagraciava-lhes 0 que sc constituira em canone inesino modermo, e idessa comum inconformidacie partiram para a asentura. Cubismo e surrealismo ultrapassadcs, era preciso assegurar nova base a concep. ção clo poema e da obra plástica. C:s rapazes discutiram longamente. chcgando à conviç̧ão de que se tornava urgente matar a figura, o asstinto, a simples e mesquinha representaçāo das coisas. E. ein segunda, inventar ou rein. ventar "cicntificamente" css a s mesmas colsas.

Num dos primeiros documentos impressos da seita - um cacerno que tem dois aros de metal à guisa de grampo - Kósice expöe ainda com incerteza os se us fundamentos e fins. "No expression - Representacion Meaning: Mirth - Negation off all Melancholy" diz-nos logo de entrada. sem razăo aparente para - uso cle uma lingua que nảo a castelhana. Seguem-se uma explicaçāo em espanhol, outra em inglès, vários poemas, alguma coisa em francès, e a gravura de um móvel invencionista, dc Roy! Consideraçöcs teóricas ainda nebulosas, porém Bayley se incumbe de torna-las mais positivas no caderno n. 2 - mais poemas,

\section{EN \\ CI \\ $\mathbf{O}$ \\ N I}

SM

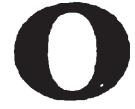

\section{CARLOS DRUMMOND DE ANDRADE}

uma página de ficção e sobretudc o manifesto "La batalla po la invencion". que nos ilustra:

"INVENTAR objetos concretos de arte, que participem da vida cotidiana do homem que ajudem a tarefa de esclarecer relacoóes diretas com as coisas que desejamos modificar: esta é a finalidade do invencionismo".

$A$ arte que existe no mundo è uma aite puramente individua lista inspirada na preocupaça que cada um tem de ser difeiente dos outros. do seu grupo. Mas fara mostrar que é diferente, deve 0 artista referir-se ao juizo alheio; assim, o seu ges. to nāo vale por si mesmo "cada livência nāo encontra sua recompınsa em sí, possui uma significacão estranha d̀ sua realidade objetiva": Procura-se represen. tar aquilo que, por natureza, re tjele qualquer representação. Surge dai a arte figurativa, que ora Evitra em declinio, e á qual Bay ley opōe a "invençảo concreta". Esta última está muito $\mathrm{m}$ a is perto dos homens' porque elimina a mania simbolista '(e simbolistas sáo considerado também os surrealistas). Enfim a otrra poética já nāo procura manter relação com algo distinto dela mesma. E preciso reconstruir o mundo. Como faze. lo? Pela "Arte Abstrata" ou me llior ainda. "Arte Concreta", ou rcja il invençăo.

Estas últimas palavras cornecem-ncs a filiação do movimento argcntino, que vcm a ser mada mais nada menos que uma continuaçāo do pensamento de Kandinski. C'umo se sabe, coube éste pintor russo, radicado na Alemanha e ultimamente exilado na França, onde morreu há pouco. aprofundar as conquistas da arte moderna no camjo da absIraçāo, de que usou largamente. Escrevencio para “.XX Siecle", cm 1938. Kandinski cmpregava as mesmas palavras que Bayle cm 1945: "a pintura chamada atstrata ou näc-figurativa, $c$ que cu bxc firo chamar concreta... -o meu desenvolvimento cio fi. gria!ivo ac abstrato (concreto, de acórclo com a minha terminologia - mais exata e mais exjressiva que a habitual - pelo menos na mímha opinião...." c incsmo Kandinski recorda que ( $3 a$ cvolução já cra visivel nas flavuras de madeira de "Klange". Itvro publicndo cm Munich. ano. da graça de 1913: eis uma ccrticläo de jdacie.

Chamar o abstrato de consre tc. o concreto de abstrato, o preto de branco. o quadiado de recicndo, é precisamente um dos direitos do artísta. E èle māo somente o chama; prova-o também. atravis da obra de arte que é uma conciliaçảo de contrários, pela sintese. E rótulos intercssam muito pouco. Mas no caso do invencionismo, coins dcutrina, e estabelecida a sua ori¿:cm. não é demais assinalar equivoco c a confusāo que se desrrendem dc sua formulaçāo es tética. Assim, declara o mani- festo da Associacion Arte Concreto - Invencion que "só por um. mal-entendido jesarista "foi róssivel chamar de abstratas as experiẹncias estétlcas. năo. r epresentativas". E O sentido antiidealista do grupo: argentino confirmado pelo seu analiste Juan Jacobo Bajarlia, num llvio interessante, rico de sugestōes sobre a poesia moderna, "Iiteratura de Vanguardia" (COlección Universal Editorial Araujo, Buenos Aires, 1946). que anota: "o materialismo dinamico da teoria é also, no terreno da arte, assim como - excusez du peu - materialismo dialético, no terreno economico...". $O$ inven. clonista pretende alcançar a ca. munhāo social pela arte pura. Nảo há evidentemente atitude intelectual mais individualista que esta - e a negaçåo extrema do individualismo, indiviclualismo é Ce resto, curioso materialismo esse, que se despoja das formas organizadas da matéria para conce. bè-las e recriá-las intelectualmente ao sabor do espirito de invenção de cada qual, que é justamente vor onde uns nos distinguimos dos outros.

Chegamos afinal á aftrmaço implicita de todo gratuita, de que a arte figurativa é idealista c a arte abstrata (perdăo! concreta) é materialista, como se materialismo e espiritualismo nāo pudessem. Insinuar-se em qualquer modalidade de expressio aristica.

A estética invencionista deve apresentar obras assexuadas, de onde a curva estejar proscrita, porque a' curva, por seu sensualisino, nos lembra a flgura, a anedota, a circunstancia subjetiva; que nāo interessa ao puro ccinceitualismo. Por sinal que foi aí que se manifestou a cisăo entre os estetas: em defesa da linha curva (e queim, entre nós humanos, näo a defenderia?) separou-se o sub-grupo Madi (palavra inventada, como convinha). que, posto advogue uma arte "matematica, fria, dinamica, ce rebral e dialética", recomenda em francés: "preciso manter alerta os sentidos."

Este em linhas gerrais, :0 "novo humanismo" que no tyem do Prata, e que Bejarlia considera a primeira tendéncla de vañguarda críunda da América Espanhola. Mas receio muito que náo seja criginal, e nada haja inventado.

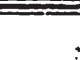

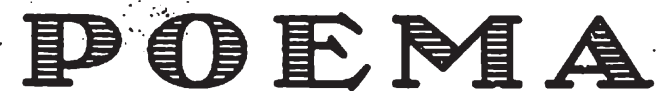 \\ Animal de tração envelhecido no trabalho e no sonho do ouro meu corpo quis voltar para onde nasceu, quis deixar que aqui o coração uivasse através da noite comc um lobo ermo, castrado por pedras e silêncios. \\ Quando éste antigo vale de novo se abriu a seus pés a palavra de maldição pronunciada contra a vida caíu da sua bôca, como a língua de um enforcado; as somb:as, ao longe flutuando, ficaram sendo seus pulmões e sentiu cada árvore séca como joelhos seus.}

Nomes das mulheres que éle amou iroje renegam sua carne infiel e seu sangue, que ilumincu o sonho e a nudez de aldeãs mas que se recusou a amadurecer o verde fruto que elas the [ofereceram;

nào mais se debruça sôbre os espelhos confidentes, cobertos agcra de parasitas mineirais; aves a peixes palúdicos das margens do brejo já o têm na retina, confundido ccm outras coisas mortas. entre as refletidas ruinas ogivais das áfuas, dos bosques e das estradas.

E pela madrugada èle se esquece, latindo à beira do areal invencivel,

os pés subindo em sua própria sombra, como em um muro. $E$ seu $\epsilon c o$, à luz da lua, vai falseando nas armadilhas perdidas.

O silêncic é uma coroa de gêlo que o outono formou em sua [fronte;

labelos e unhas ainda estão crescendo nele, como num morto. Gemidos dos alicerces, sombras e moscas dos escombros pcusam na sua face.

\section{WILSON DE FIGUEIREDO}


A partir da publicação em Poesía Buenos Aires de "Búsqueda de la poesía" (n.15, outono de 1954, versão em prosa de "Procura da poesia" incluído em a Rosa do povo, de 1945), arte poética em principio negativa e até próxima dos fundamentos invencionistas: "No hagas versos sobre acontecimientos. (...) La poesía (no extraigas poesía de las cosas) suprime sujeto, objeto [...]"3, e "El obrero en el mar" (n.30, primavera de 1960, tradução de "O operário no mar", de Sentimento do mundo, publicado em 1940, feita por Rodolfo Alonso), podemos arriscar imaginarmos um Drummond formando parte da constelação Arturo. Nesse sentido, a aparição de Koellreutter, Raúl Lozza e Murilo Mendes na revista Joaquim pode nos ajudar a fundamentar com uma ênfase maior sua posição dentro das derivas não figurativas do Prata, pois eles pertenciam de fato àquela constelação. Acompanhando o Manifesto Invencionista do grupo Arte Concreto Invención, Drummond (re)publicou no número 9 de março de 1947 da revista Joaquim o seu texto "Invencionismo" (Figura 2).

Nesse artigo, um Drummond muito informado sobre o movimento esboçava uma história do grupo invencionista desde finais de 1943 quando, depois de discutirem longamente, aqueles rapazes do movimento chegaram "à convicção de que se tornava urgente matar a figura, o assunto, a simples e mesquinha representação das coisas. $E$, em segunda, inventar ou reinventar "cientificamente" essas mesmas coisas" ${ }^{4}$, até os contemporâneos manifestos assinados por Edgar Bayley sobre a invenção concreta, que estaria "mais perto dos homens porque elimina a mania simbolista" e que tentaria reconstruir o mundo a partir de colocar a obra poética em relação com algo distinto dela mesma. Drummond encontra nas palavras de Bayley e no movimento todo uma continuação do pensamento de Kandinsky que já em 1938 se referia a sua pintura enquanto abstrata, não figurativa ou, melhor, concreta e que, muito antes, no seu livro publicado em Múnich em 1913, Klange, que reunia reproduções de gravuras em madeira, já tinha começado a pesquisar. Essa é, segundo Drummond, a certidão de idade do movimento argentino, o que restaria, no caso, "originalidade" ou "invenção" ao grupo. Além disso, critica o anseio de alcançar a comunhão social pela arte pura, sendo uma contradição do materialismo defendido pelo grupo ao se manifestar contra o individualismo mas pregando pela invenção e a elaboração intelectuais, atitudes e rasgos conforme ele os mais individualistas.

${ }^{3}$ ANDRADE, Carlos Drummond de. Búsqueda de la poesía. Poesía Buenos Aires. Edição fac-similar. Tomo I. Buenos Aires: Biblioteca Nacional, 2014 [n. 15, out. 1954], p. 159.

${ }^{4}$ Idem, Invencionismo. Joaquim, Curitiba, n.9, p. 13, março de 1947. 


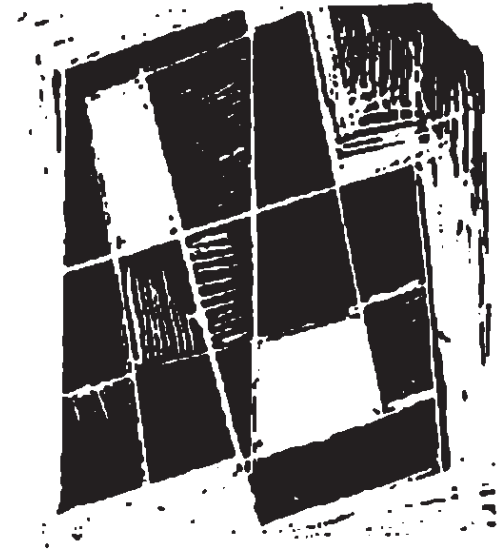

\section{Jorge Souza}

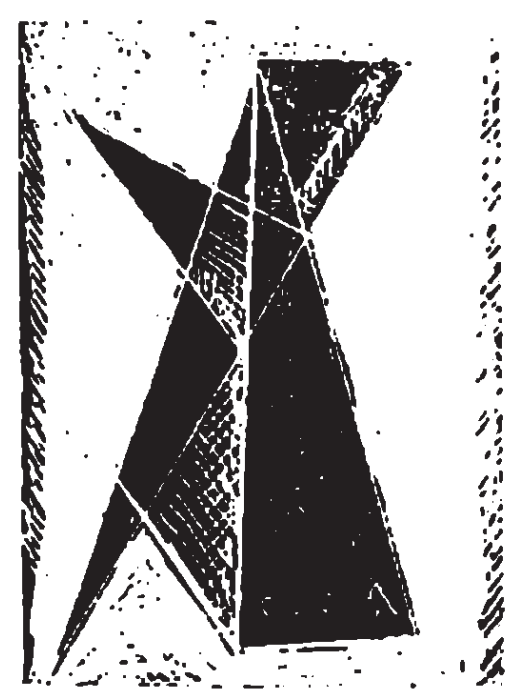

\section{Primaldo Monaco}

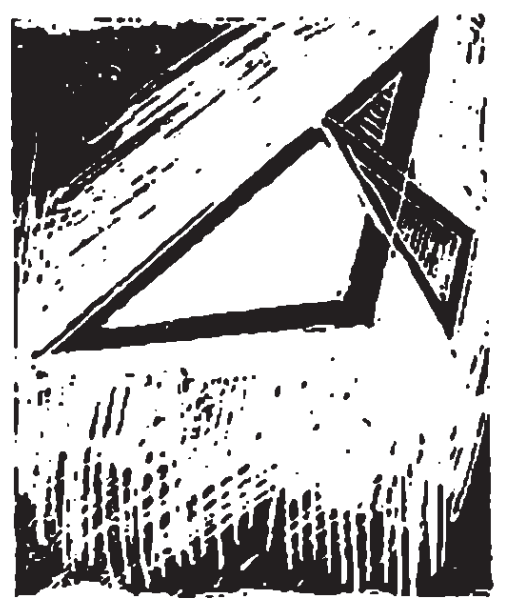

Raulllozza

\section{MANIFIESTO INVENCIONISTA}

La era artistica de la ficción representativa toca a su fin. El hombre se forna de más en más insensible a las imágenes ilusorias. Es decir, progresa en el sentido de su integración on el mundo. Las antiguas lantasmagorias no satisfacen ya las apetencias estéticas del hombre nuevo, formado en una realidad que ha exigido de él su presencia total, sin reservas.

Se clausura asi la prehistoria del espiritu humano.

La estética cientifica reemplazará a la milcnaria estética especulativa e idcalista. Las consideraciones en torno a la naturaleza de lo Bello ya no tienen razón de ser. La metalísica de lo Bello ha muerto por agostamiento. Se impone ahora la fisica de la belleza.

No hay nuda esotérico en el arte; los que se pretenden "iniciados" son unos lalsarios.

El arlc reprcscntativo muestra "realiclades" estúticas, ibstractumente frenadas. $Y$ es que todo el arte representalivo ha sido abstracto. Sólo por un malentendido idealista se dio en llamar abstractas a las experiencias estéticas no representalivas. En verdad, a través de estas exporiencias, hubiese o no conciencia de ello, se ha marchado en un sentido opuesto al de la abstracción; sus resultados, que han sido una exaltación de los valores concretos de la pintura, lo prueban de un modo irrecusable. La batalla librada por el firte llamado abstracto es, en el tondo, la batalla por la invención concreta.

El arte representativo fiende a amortiguar la energia cckncscitiva del hombre, a distraerlo de su propia potencia.

LA materia prima del arte representativo ha sicio siomgre la ilusión.

llusion de espacio.

llusion de expresión.

llusión de realidad.

Ilusión de movimiento.

Formidable espejistno del cual el hombre ha retornado siempre delraudado y debilitado.

El arte concreto, en cambio, exalta el Ser, pues lo practica.

Arte de acto; gencia la voluntad del acto.

Que un poema o una pintura no sirvan para justificar una renuncia a la acción, sino que, por el contrario, contribuyan a colocur al hombre en el mundo. Los artistas concretos no estamos por encima de ninguna contianda. Esta- nos en todas las contiendas. Y en primera linea.

No mis el arte como soporte de la diferencia. Por un srte que sirva, desde su propia esfera, a la nueva comunión que se yergue en el mundo.

Practicamos la técnica alegre. Sólo las técnicas akotadas se nistren de la tristeza, del resentimiento y de la confidencia.

Por el júbilo inventivo. Contra la nelasta polilla existencialista o romántica. Contra los subpoetas de la pequeña llaga y del pequeño drama intimo. Contra todo arte de blites. Por un arte colectivo. 


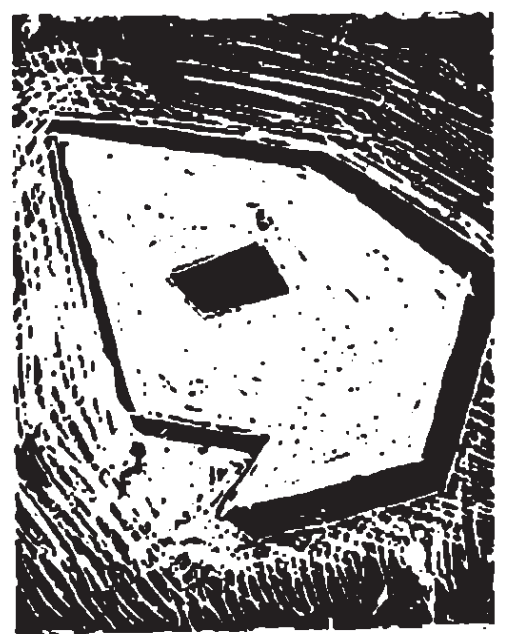

Tomas Maldonado
"Matar la óptica", han dicho los surrealistas, los ülti. mos mohicanos de la represcnlación. EXALTAR LA OPTYCA, decimos nosolrcs.

Lo fundamental: rodear al hombrc de cosas reales y no de fantasmas.

El arfe concrelo hubitúa al hombre a la relación directa :On las ccsas y no con las ficciones de las cosas.

A una estética precisa, una técnica precisa. La función estélica contra el "buen gusto". La función bianca.

NI BUSCAR NI ENCONTRAR: INVENTAR.

Edgar Bayley, Antonic Caraciuje. Simón Contreras, Manuel O. Espinosa, Altredo Hlito, Enio Iommi, Obdulio Landi, Rauil Lczza, R. V. D. Lozza, Tomás Maldonado, Alberto f.Iclunberg. Primaldo Monaco, Oscar Nuñez, Lidy Prali Icrge Sour.n. Matilde Werbin.

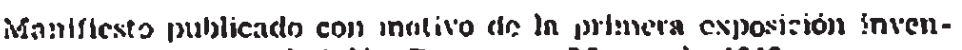
(4) Mntsta, realirada en el snlón Peuxer en Marzo de 1946.

Figura 3 - "Manifiesto Invencionista" do grupo Arte Concreto-Invención re-publicado no número 9 da revista Joaquim, Curitiba, março de 1947

Do lado do texto de Drummond, na página anterior e em espanhol, aparecia o Manifesto Invencionista publicado, segundo consta na nota de rodapé, com motivo da primeira exposição invencionista, realizada no Salón Peuser em março de 1946, um ano antes (Figura 3).

"La era artística de la ficción representativa toca a su fin" 5 , era a frase que começava o manifesto e, conjuntamente, dava início a uma nova era histórica, fechando a assim chamada "pré-história do espírito humano". Indo contra a ilusão que define toda representação, a arte concreta era uma "Arte de acto; genera la voluntad del acto"6, procurava ser uma arte coletiva, exaltava a óptica e chamava, a partir da invenção, a "rodear al hombre de cosas reales y no de fantasmas". ${ }^{7}$

Em outro breve texto da época atribuído ao próprio Edgar Bayley que funcionava a modo de apresentação da Exposición Arte Concreto Invención, realizada pela Sociedad Argentina de Artistas Plásticos na Galería de los Artistas, em outubro de 1946, se afirmava que a arte concreta constituía "la culminación de un proceso estético, iniciado en la segunda mitad del siglo anterior, bajo

\footnotetext{
${ }^{5}$ BAYLEY, Edgar; et al. Manifiesto Invencionista. Joaquim, Curitiba, n. 9, p. 12, mar. 1947.

${ }^{6}$ Ibidem, p. 12.

7 Ibidem, p. 12.
} 


\section{la influencia de las nuevas condiciones sociales y técnicas determinadas por la revolución industrial"8 que levou progressivamente a arte a se afastar daquilo entendido como "realidade".}

\section{FUNDACION ESPIGAS \\ Buenos Aires - Argentina \\ EXPOSITORES}

Antonio Caraduje

Manuel Espinosa

Alfredo Hlito

Enio Tommi

Raúl Lozza

Tomás Maldonado

Alberto Molenbery

Primaldo Mónaco

Oscar Núñez

Lidy Prati

Jorge Souza

Juan N. Mele

Gregorio Vardanega

Virgilio Villalba

ESTA PUBLICACION HA SIDO GENTILMENTE DONADA POR Poverar M. Gonzacob
El arte concreto constituye la culminación de un proceso estético, iniciado en la segunda mitad del siglo anterior, bajo la influencia de las nuevas condiciones sociales y técnicas determinadas por/la revolucion industrial. En el curso de ese proceso, la obra de arte se ha ido cumpliendo a través de un alejamiento, cada vez mayor. de lo que el público generalmente ha entendido yentiende por realidad Pero esta característica - comin a la mayoría de los movimientos illamados underues- lejos le implicar una neqación de los valores bumanos y estéticos ha hecho posible, en la príctica la más rotunda a firmación de la capacidad inventiva del hombre.

Los artistas concretos han tomado conciencia de este proceso $y$ han proclamado una estética, según la cual el valor de una obra depende, exclusivamente, de la invención de sus relaciones internas, $y$ no de una anecdota representada. Es decir, que niegan el valor estético de las ilusiones, en que se basa la técnica representativa, y exaltan las funciones específicas de la obra de arte, antiguamente colocadas al servicio de la copia o la descripción.

La obra adquiere asi una realidad indiscutible. Constituye una materia real de conocimiento o de experiencia directa para el hombre. $y$ no un sistema de engaños surgido de su miedo. Los nuevos artistas transforman. de este modo, cada obra en un activo factor revolucionario, enderezado a adecuar el campo de la sensibilidad humana para el ejercicio de nuevas facultades, Es decir, que por primera vez el artista concreto se propone, conscientemente, hacer de la obra una forma de la práctica humana.

En el nuevo arte. la pintura, la música o' el poema han dejado de ser parásitos de to esotérico o lo desconocido. Esa exaltación permanente, que el artista representativo pedía en vano al misterio o a la imagen ilusoria, es en el invencionismo función de las virtudes estéticas concretas de la obra. Por lo tanto el arte concreto ha convertido lo maravilloso en una realidad cotidiana, en una experiencia habitual del hombre.

Los pintores concretos se han propuesto en sus obras no sólo afirmar la realidad material de las zonas coplanarias, su bidimensionalidad, sino también inventar totalmente las pinturas, para lograr de este modo una estructura integral.

En el arte de espacio, la milenaria estructura escultórica, basada en el équilibrio de volúmenes, ha sido reemplazada por la relación invencionista de las direcciones de profundidad.

En la música, las formas antiguas han cedido el lugar a una composición puramente elementarista, liberada de los ancentrales resabios represcntativos.

En la poesia, el concepto inventado, en oposición a la imagen descriptiva, tiencle a hacer de cada poema. no ya una enunciación de objetos. sino una forma de elevada expe. riencia mental:

Invitamos a Vd. y Flia. a la inauguración que tendrá lugar el viernes 11 de Octubre a las 18.30 horas.

Figura 4 - "El arte concreto constituye la culminación de un proceso estético", atribuido a Edgar Bayley. Exposición Arte Concreto Invención. Buenos Aires:

Sociedad Argentina de Artistas Plásticos Galería de los Artistas, 1946

Essa arte óptica e direcionada ao ato, assim e então, se propunha modificar as formas de vida. Em "Sobre la invención poética", Bayley se dedicava mais à poesia dentro dessa práxis invencionista:

${ }^{8}$ BAYLEY, Edgar. El arte concreto constituye la culminación de un proceso estético. Exposición Arte Concreto Invención. Buenos Aires: Sociedad Argentina de Artistas Plásticos, Galería de los Artistas, 1946. 


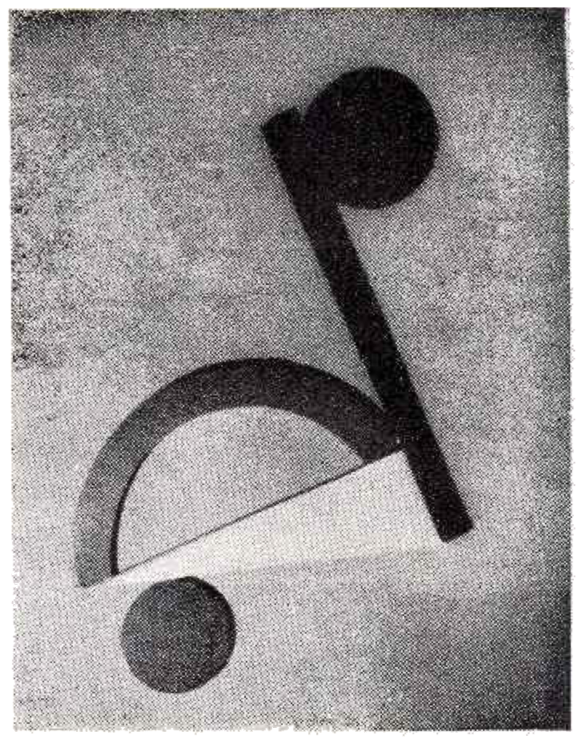

Alfredo Hlito

\section{SOBRE INVENCION POETICA}

El concepto inventado, que es la base de la nueva poesíx, constituye una de las formas de la praxis revolucionaria. A través de su invención, el poeta se integra en el mundo; es decir. que participa activame ste en la larea teórico-práct ca de trans. formarlo.

Lo que se revela hoy ineficiente, en la antigua estética, es el intento de relacionar e' poema con objetos determinxdos, fara darle asi una significación lógica.

La poesía vive de una relación con la tstalidad del mundo, y no con una parte de él.

Las experiencias poéticas de los últimos años han permitido conocer algunas formas de la actividad creadora del hombre, que habian permanecido, hasta ese momento, confundidas con otras funciones, especialmente con las de comunicac ón o expresión. T'ales experiencias han abierto el camino para 'a concepción es'ética invencicnista.

Un poema debe constituir un hecho.

Vivir el poema como un acontec miento de nuestra vida mental, y no como una re. piesentación en la que somos meros espectadores.

La técnica surrezlista, en virtud de su carácter descriptivo. coloca con tresuencia el foema en función de realidades que le son extrañas. No procede a construir una realidad poética (combinación de conceptos inventados), sino que toma el hecho surrealista y se limita a describirlo.

El poeta no canta ya parcelas del mundo, porque ha comp:endido que su oficio no reside en la mera enunciación de objetos, sino, en el más esencial, de producir en cada hombre una relación poética con la totalidad de las cosos y de las situaciones.

Hay un desarrollo histórico de las formas poéticas, que podemos explicar con respecto a los cambios sociales y económicos, pero hay también una función cie la poesía. que se ha ejercido a través de los más diveisces esti os creadores, y cuyo carácter interesa definir.

Por esa función, mucho más que po: el tema o la anécdota, la obra poética se ha convertido en una forma de conocimiento y de vida; ha establec do relaciones men. tales con el mundo y hx sostenido el júbilo creador en la aventura humina.

Ia poesia invencionista persigue una 1 zmiliaridad con lo deszonocido.

\section{EDGAR BAYLEY}

Figura 5 - "Sobre la invención poética" de Edgar Bayley publicado no número 1 de Arte Concreto Invención, Buenos Aires, agosto de 1946 


\section{História Contemporânea}

\section{TEATRO}

Ibsen era grandioso demais, demais coletivo, próximo portanto das origens veridicas do teatro - festa popular e grande catarse... Ressalta, pois, de tu. do isso, o caráter religioso do teatro, festa coletiva, festa de massa, festa do povo, cujo sentido já é modernamente e vagamente procurado em Shav e no passional americano, O'Neill. A França deu, nestes últimos tempos, tambem umia grande farsa, que nāo fica longe dos mistérios medievais, ou melhor, das suas grandes jocosidades que Jacques Copeau yeconstituiu nos dias magnifi$\cos$ do Vieux Colombier. Foi o Ubu de Jarry onde o Rabelais represado pela burguezia de bons costumes, que vem de Le Sage a Flaubert, havia de trazer a nós todos a esperança da sua imortalidade. O Ubu-Roi de Jarry, as poradas sensacionais do Cocteau da Tôrre Eifel c uma grande forma nova de teatro encontrada no ballet, tiveram sua expressão, seu denominador comum, num homem que seris o único capar de realizar o grande espetáculo moderno que devia ser a ópera. Se houve ùltimamente um gênio em França, êsse se chamou Erik Satie. .

Osuald de Andrade

\section{PINTURA ARGENTINA}

Entre nós (Argentina) as

theos do Brasll. E, depols, Pampulha, onde as construcbes que promoveu estao todas ineptradns num sentido de renovecto. A Igreja, por exemplo, aboolutamentr dentro do eapirito de arte nova, nio tem aparato dos altares a que extemos habltuados, of imples, decorada com painéls de Portinarl, que tratou os temas biblicos dentro de formas modernisclmas, com o seu statema do sombras cortadas, e tudo o mals. k: Minas nflo ache que o seu catolicismo se abale por causa die. oo. Palel ne Igreja. Poderia inlar no teatro, no carstino. cheloo do sentldo de renovecto. Clschlatt, de quem is faled, conquletou o seu premio de viscem i EUrops Justamente com quatro altorelevos modernos pere a Itreja de Pampulha. Mas, alo 6 a cançaram um hierarquia mais elevada, que as torma respeitáveis não só em nosso país como no estrangeiro. Portm, cxiste uma plástica argentina? Somos um pais eminentemente agrícolo-pecuário. Esta preponderância das indústrias mais condicionou a produção artística orientando-a para a paizagem, os animalistas, etc. A paizagem argentina em sus contextura geral é anti-plástica. Pampa imenso que a cordilheira limita por um lado, e o oceano por outro, com uma leve ondulação aqui e ali que não altera a definição geral. A plástica é a arte dos valores tactis; o horizonte é sua antitese. Os indios primeiro, os espanhóis depois, e os criolos em seguida, dobraram-se à sua influéncia e nossa organizaçāo nacional não conseguiu iludir a pressão de um tão influente imperativo. Por isso a arte argentina nada pode nem deve esperar dessas três fontes evidentemente negativas. As belas artes, entre nós, se cingiram, desde os seus balbúcios a tutela européa.

\section{Leonardo Estorico}

\section{NATAL}

Nenhum poema superior ao telegram de Nova York, cujo autor permanecerá anónimo pelos séculos; telegrama que o poeta nāo compoz, nāo poderia compor: "Nova York ,26 (H.) - $\mathrm{O}$ número de aciden tes ocorridos nos Estados Uni-

Pampulhe. Alnda agora, Culgmard fol contratado por dols anos, para enslnar desenho a surbada de Belo Eorizontel exte 0 camlnho que temos de segult.

De outro ledo, falts-nos uma critlca orientadore nonesta 20 modo do que exth reallando Campoflorito no Rio, uma critica que entenda, para noo flcar em apreclacbes meramente literirias: "Fui so Ballo e vl umas belas gardenlas de Fulano." Campoftorito nlo \& um pregador de Idelas noves, mas epenes um critfco nonesto, que fulge para ortentar. Preclsávamos de algruma colsa semelhante. Altm diseo, crelo que nos fas uma certa falta a factlldade de ter regularmente boas rovistes eopectalliadns de arte. Ii neceachirto que alruom culde de ircports-las para o noses melo. dos durante as festas do Nat:al
foi particularmente elevado. Houve duzentas mortes, das quais cento e trinta em conse. qüència de desastres de automóvel. Ocorreram dois encontros entre automóveis e trens nas passagens de nivel da linhu Batavia-Nova York, nos quais pereceram sete pessoas. Em un encontro dessa natureza em Charlotte, na Carolina, houve nove vitimas. Em Sacramento, na Califómia, explodiu a locomotiva de um trem expresso, matando os dois $\mathrm{ma}$ quinistas. Vinte pessoas morreram no incèndio de un hot:-l de Springfield. O consumo de licores adulterados ocasionou no Estado de Massachussets nove mortes".

\section{Drumond de Andrade}

\section{AS QUATRO LIBER- DADES}

Temos de procurar, em dias futuros, por cuja serenidade ansiamos, um mundo que se baseie em quatro liberdades humanas essenciais. A primeira é a liberdade de expressāo e de palavra - em tôdas as partes do mundo. A segunda é a liberdade de cada qual adorar a Deus a sua maneira em tidas as partes do mundo. A terceira é a libertação da miséria - o que, trazido a têrmos universais, - significa o entendimento económico que venha a assegurar, em cada nacão, uma vida saudável e paci. fica para os seus habitantes em tödas as partes do mundo. A quarta é a liberdade do temor - que, em tèrmos universais, significa uma redução mundial dos armamentos, a tal ponto e de tal maneira comple ta. que nenhum país possa ocliar-se em posição de come ter ato de física agressão contra seus vizinhos - em nenhuina parte do mundo.

Franklin Delano Roosevelt

\section{AMERICA}

a América tem que ser criada pelos artistas. Quero dizer artistas de tôda a ordem: artistas do pensamento e da palavra. da arquitetura, das fornas plásticas, da música; também artistas da lei, da concórdia e da ação. Só os artistas podem criar a América, e só ne medida em que hajam cumprido a sua tarefa de criasão, poderăo os políticos e at críticos levar avante o que tenha aido criado. Só na medida em que os artistas hajam criado a América, poderão os povos da América sentir e desfrutar a sua América. Percebeis que se trata de uma obra de arte no mais amplo sentido da palavra arte. Arte implica beleza. Porém o sentido da beleza não é mais do que uma consciéncia cabal da vida. Beleza quer dizer participaçäo consciente na vida. A América que devemos criar deverá ser, pois, mais consciente, mais viva, quer dizer, mais bela do que qualquer mundo do passado. Tomemos por exemplo a Grécia, a India ou o Egito. Grandes mundos, certamente, cada um a seu turno. Porém. quāo reduzida porçāo do organismo humano de tais mundos participou realmente em sur cultura e em sua beleza! Na Grécia, uns quantos patricios cimentavam sua bela obra sóbre uma obscura massa de escravos. $\mathrm{Na}$ India e no Egito só possuiam a luz os homens da casta sagrada, ocultando-a zelosamente à cegueira das massas anónimas. Não só estava desterrada do consciente e ativo esplendor da cultura a imensa maioria dos homens, mas a maioria das mulherea. Aquelas nāo eram culturas de humanidade; eram só culturas de classe, de diminutas, insolentes minorias, que exploravam o todo. E em quási todos os valores e na ideologia que herdamos, encontramos èsse sentido de cxploração, èsse dualismo, essa exclusividade. Nem siquer pode dizer-se que a terra tenha visto uma raça de homens que viva, integralmente, sob o fogo da mesma luz. E até que èsse dia chegue, a raça humana viverá mutilada: será como um corpo separado de sua alma, como um corpo só em paite sustentado pelo aliniento e pela luz, enquanto outra parte enlanguece sem èles. A América foi fundada para 
O poema, em relação com a totalidade do mundo, deve constituir um fato e o poeta deve se preocupar em "producir en cada hombre una relación poética con la totalidad de las cosas y de las situaciones" para que, por fim, a obra poética possa se converter em uma "forma de conocimiento y de vida". 9 Agora, então, não poderiam ser consideradas atos poéticos destinados a mudar a percepção óptica e as formas de conhecimento e vida as outras intervenções que Drummond teve na revista Joaquim e, dentre elas e especialmente, o ready-made intitulado "Natal"? (Figura 6).

Nesse atlas heterodoxo que foi a seção História Contemporânea, que reunia numa montagem assombrosa breves textos das mais diversas procedências, apareceu imediatamente depois de "Pintura argentina" de Leonardo Estarico, cuja posição, seja dito, negava a possibilidade da mera existência de alguma coisa perto das vanguardas invencionistas e pregava nas artes pela tutela europeia dada a falta de possibilidades que o ambiente natural e a indústria agrícola-pecuária argentina significava para os artistas, "Natal" de Drummond. Claro que aqui já não se trataria tanto de invenção senão de re-invenção, e nesse seu re-invencionismo Drummond também estaria dando crédito à mudança óptica do objetivo poético que, fundamentando-se num fato jornalístico, modifica as formas de vida e conhecimento, sendo com isso a poesia um ready-made e uma arte do ato, uma arte coletiva, que exalta o óptico e o háptico e que, repetindo, cria a possibilidade de outras possibilidades dentre a infinidade de mundos possíveis ainda não realizados senão por ecos, gestos e vestígios.

No seguinte número da Joaquim, Drummond volta aparecer na seção "História Contemporânea". Depois de um breve fragmento de "A um jovem poeta" de Rilke onde se lê: "Não escreva poemas de amor. Procure, de início esses temas excessivamente comuns: são os mais difíceis"10, depois de "A crise do espírito" de Maggie Guiral e de "Catolicismo" de Tristão de Ataíde, apareceu um trecho entre aspas intitulado "Propondo a volta à realidade" do próprio Carlos Drummond de Andrade onde, frente à preocupação dos aca-

\footnotetext{
${ }_{9}^{9}$ Idem, Sobre la invención poética. Arte Concreto Invención. Buenos Aires, n. 1, p. 13, ago. 1946.

${ }^{10}$ RILKE, Rainer Maria. A um jovem poeta, Joaquim. Curitiba, n. 2, p. 8, jun. 1946.
} 
dêmicos pela morte do modernismo, chamava a voltar o olhar às coisas que estavam acontecendo nesse momento e trocar o assunto da sobrevivência do modernismo por aquele outro da sobrevivência humana:

\begin{abstract}
A mesquinha irritação contra um movimento literário aparecido há vinte anos atrás e que já realizou o seu ciclo, torna-se mais ridícula diante da luta que envolve hoje toda a terra e na qual o Brasil assumiu uma posição definida e tem um papel a cumprir. Proponho o encerramento desses debates pueris e a volta à realidade. A realidade chama-se Pearl Harbour, Malta, Londres, Stalingrado, Guadalcanal, Egito, luta de morte contra o nazismo. ${ }^{11}$
\end{abstract}

Esse Drummond engajado e realista ou realista e engajado será o mesmo que assina a carta endereçada a Dalton Trevisan, enviada do Rio com data de 5 de maio de 1946 e que a Joaquim reproduziu no mesmo número 2, na página 17:

\begin{abstract}
Estou recebendo o primeiro número de "Joaquim". Ainda bem que continuam a surgir no Brasil as revistas de moços. Porque os velhos e os simplesmente maduros estão calados, e na sua plenitude parece que desistiram mesmo dessa tarefa que toda geração se impõe quando está nascendo: reformar a vida, ou simplesmente a literatura (deixar de consegui-lo não tem importância; o lamentável é desistir de tenta-lo). [...]

Nosso poder de admiração vai se tornando tão familiar e nosso poder de destruição tão débil, que a insubordinação dos moços, neste ano de 46 , é quase um espanto. ${ }^{12}$
\end{abstract}

E será também esse Drummond engajado e realista ou realista e engajado quem publicará os poemas, no número 7 da revista, "A Federico García Lorca" e, no número 8, "Canção amiga" que, salvo pequenas diferenças na disposição espacial dos versos e a troca de "muitos países" por "vários países" no segundo poema, apareceram depois em Novos poemas de 1948, continuando a criação da figura da aurora presente em seus livros anteriores.

\footnotetext{
${ }^{11}$ ANDRADE, Carlos Drummond de. Propondo a volta à realidade. Joaquim, Curitiba, n. 2, p. 9, jun. 1946.

12 Idem, Carta a Dalton Trevisan. Joaquim, Curitiba, n. 2, p. 17, junho de 1946.
} 
A última intervenção de Drummond na Joaquim é curiosa. Num breve texto intitulado "NOVISSIMOS", aparecido no penúltimo número da revista, o número 20 de outubro de 1948, começa constatando o retorno - com sucesso - das declamadoras em parte devido a inclusão no já tradicional repertório delas da poesia dos novíssimos, corolário último da, por ele chamada, revolução modernista, agora já fagocitada pelo popular. Com ironia melancólica, fecha o texto dizendo: "Quanto a nós, remanescentes da "escola" vencida, os párias do verso livre, jamais declamáveis - tempo é de reconhecer a derrota. Eia, pois, irmãos! Amarremos a trouxa e, à sorrelfa, piremos". 13

Com essa participação de Drummond na Joaquim, introduzindo com uma série de críticas no Brasil o invencionismo, praticando o ready-made e a intervenção intempestiva do fragmento e lembrando, também, as outras de Koellreutter, Murilo Mendes e Raúl Lozza, será suficiente para deslocar a Ilha de Martim Garcia e acenar o projeto curitibano à área banhada pelas vanguardistas aguas do Prata que refletiam o céu da constelação Arturo? Já o brevíssimo texto assinado por Portinari e que estava ao lado do anteriormente citado de Drummond, "Novíssimos", responderia negativamente à pergunta: "A tendência hoje é para a arte figurativa - para o realismo", afirmava categórico. ${ }^{14} \mathrm{E}$ continuava: “Uma arte mais legível. Uma arte que o povo possa compreender. Isso não quer dizer uma volta e nem uma arte académica. Mas uma arte para o povo e não para meia dúzia de viciados em folhinha e nem para os Snobs." 15 E ainda menos ficaria do colocado na pergunta depois de chegar a um dos últimos textos publicados pela Joaquim: "Defesa do realismo", de Héctor P. Agosti, aparecido anteriormente no número 3 da revista Contrapunto de Buenos Aires, em abril de 1945 (Figura 7).

\footnotetext{
${ }^{13}$ Idem, "Novíssimos". Joaquim. Curitiba, n.20, p. 5, outubro de 1948.

${ }^{14}$ PORTINARI, Cándido. "A todos os Joaquins do Brasil". Joaquim. Curitiba, n.20, p. 5, outubro de 1948.

${ }^{15}$ Ibidem, p. 5.
} 


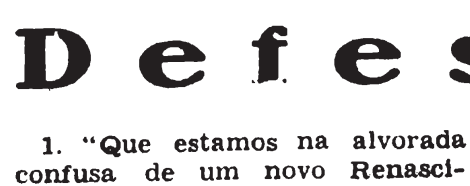
mento, quem poderia negá-lo? Pustigados poi acontecimentos cesivos que demonstraram a falibilidade de certas normas de vida supostamente inalteráveis, nâ o requer muito esfôrço descobrir que uma nova conduta integral há de plasmar-se em meio à derrocada. E esta conduta integral há de assinalar-se - já o está - por uma exaltação do homem. de suas inquietudes e aspiraçōes secretas ou ruidosas, algo assim como o regresso daquele obscurecimento humano que a arte abstrata proclamou com orgulhosas vozes de desafio

2. "A creaçāo artística como torma particular do conhecer, se apresenta agora como um jôgo de ida e volta entre a ação da realidade e a reação da consciéncia. Instalado no meio de seu mundo, o artista, ao contrário do cientista, propóe-se reproduzir o essencial da realidade em forma de singular. Não se erige em demiurgo dos objetos, senão que aspira a conhecer os objetos que subsistem fora dele com majestosa - ainda que submissa vida autonoma. Mas se o conhecer é um reflexo da realidade, estulto seria o artista que acreditasse na possibilidade de um reflexo simples, imediato, puro de base estritamente sensorial. como um ato semelhante à impressáo de uma placa fotográrica. Sua grandeza reside nesta segurança de transformar-se de servente em amo dos objetos. Por sua dialética de mobilidade o conhecer realista nos resguarda da impassivel fixidez metafisica e, ao mesmo tempo, nos libera da eterna coerção dos objetos. Porque o pensamento - partido da ação sobre o real para atingir aos mais audazes designios da abstraçāo - é, em ultima analise, senhor do real, mas é também uma antecipação do real nos quadros fugidios do possivel".

3. "No novo realismo, de raiz discursiva e dialética, aspira-se abstrair o mundo possivel entre as premonições do mundo real $E$ que o mundo real se apresent. ao artista como uma massa confusa de sucessos, cujo sentido recôndito permanece frequentemente desfigurado pelas aparências extrinsecas que é preciso ( esmontar implacavelmente. $O$ novo realismo supõe que os sucessos exercem uma ação sobre o artista; este, porém, por sua vez, traslada a reação de sua consciência sobre a realidade exterior que o estimula, quasí "cmpre em consonancia com as idéias gerais de seu tempo, que são, por sua vez, expressão antecipada, simultanea ou tardia de um sistema de relaçōes sociais. A realidade contém multiplas representações coerentes, e na seleção de cada uma delas, no roleiro expressicnal de um artista ou nas modificações de uma obra desde seus primeiros esboços até ‘ua final concepras, essa luta dranática entre o mundo dos obje-

\section{Héctor P. Agosii}

tos e o sujeito sensivel que pretende penetrá-lo, essa luta treinenda de intercâmbios entre a realidade do mundo e a consciêncla do artísta, essa substituição dilacerante dos signos apreendidos pelos signos que é preciso inyentar para redimir as essências, tudo isso constitui, por assim dizer, o mecanismo psicológico deste processo creador que tem constituido sempre a nutriçâo dolorosa do verdadeiro artista. Este processo supōe necessuriamente uma psicologia e uma sociologia do ato creador, porcue a consciência individual do artista está submergida num complexc social cujas consequencias padece, ainda que, por vezes, suponha não perceber".

4. "Se o processo do conhecer é um jôgo de açōes e reaçōes reciprocas entre a realidade e a consciência, o realismo dinamico nāo imagina que constrói os cbjetos em si, porém tampouco e resigna a resgatá-los com passividade receptiva de um espelho. Seu ideal estético consiste na tradução da realidade através do temperamento, porque o homem, em ultima instancia, torna a assinalar-se como medida e finalidade das coisas. Este homem, porém, não é, apesar de tudo, o ente absoluto que os sequazes do subjetivismo imaginavam. O homem é um homem real, absorvido nos embates de seu tempo, modificado em seu intimo pelas relaçōes sociais, constragindo a plasmar sua cons ciência individual em conjuncaao ou oposiçāo à ordem vigente; a inda que, afinal, se estabeleca nessa realidade que procurará conservar ou modificar de acordo com seus impulsos ou interesses. Esse homem de carne e osso é o que parte a conquista artistica do mundo material, exterior e anterior a ele. Esse homem, porém, convertido em artista, se não é um demiurgo dos objetos como pretendiam os abstratos, tampouco é o registrador dos objetos como supunham os naturalistas. Deixa de ser as duas coisas antagonicamente para ser ambas simultaneamente. Elevado à consciência de seus fins como artista e como homem, é agora um "transformador" de energia, porque seu realismo - segundo a exata definição de Aragon deixa de estar dominado pela natureza, ao apropriar-se das realidades sociais que procuram modificar a mesma natureza".

5. "E a capacidade de sonhar realmente - de sonhar nas colsas e entre as coisas - pressupõe, no realismo dinamico, una invençāo do concreto que se equipara à reprodução do concreto. O concreto pode reproduzir-se; mas. o concreto também pode inventar-se artisticamente como ưma antecipação do possivel entre as malhas cerradas do real. Num ensaio sagaz, Max Raphael ssegura que as obras de arte podem "conter mais do que sua época lhes oferece concretamentc, na medida em que reproduzem material ou formalmente coletivizações pertencentes ao passado ou imaginárias". No fundo das "coletivizaçōes imaginárias" não está encerrada essa previsão de futuro que o realismo dinamico subtrai do presente mediante a projeção de sua consciência dialética? E nāo se cleduz dêsse fato que na doutrina do novo realismo a arte não é só uma reprodução senāo tamlém uma revelação, em que as formas lucidas do conhecimento recebem muitas vezes o impulso a antecipação de certa intuição germinadora? Esta intuição reveladora - que é como uma luz repentina no duro embate das formas e dos temas - se conjuga com aquela abstraçāo di realidade essencial, sem cujo virial exercicio a realidade se no desvaneceria ou se nos desfigu raria ante a inesgotável multitude dos fenomenos. Como poderiamos conhecer a realidade verdadeira se não fossemos capaze: de abstrair, por um ato de consciência reflexiva, tua essêncria primordial e definidora?"

6. “A abstração, porém, ainda que esboce a realidade primor cial, não é, todavia, obra de arte senảo conhecimento. Tal conhecimento do real logo será obra obra de arte realista quando se transforme em substancia sensivel, isto é, quando aquela realidade se traduza através do temperamento do artista. Influenciado ou modificado quanto queira pelo extravasamento social ou relas apetencias ideológicas, esse temperamento individual, afinal de contas, está obrigado a proporcionar a nota de sua psicologia pessoal no vasto tumulto de vozes que povoam o universo. Deste modo, no meio de semelhante jogo de ações e reacöes reciprocas, o conhecimento se converte em obra de arte: quando aparece a capacidade de sonhar, que é algo como a previsão do futuro no presente, a reconquista do presente no passado".

7. "Para o realismo, em ultima instancia, o homem torna a assinalar-se como centro do nundo, e é neste sentido antropomorfico que se pode falar de um novo renascimento, de uma nova sultmissāo às essências terrenas.

A desumanização havía signicicado nada menos do que a re volta fecunda contra a triviali cisde do antigo realismo antipoético. Mas em virtude dessa cougnáncia a reconquista do valores estetices da forma ficava cleteriorada pelo abandono dos valores éticos do conteúdo. desprezo do têma especialmente cm pintura, derivava-se de uma inaoncebivel confusāo entre nedota, que é a exterioridade transitoria do têma, e o têma mesmo, que é o intersticio para a introdução na essência ultima cia realidade. A revolução abstra-

ta foi, assim, por muito tempo, um heroico ascetismo das formas, uma tortura interminave para despojar as formas de toda substancia carnal, para fazê-las librar por sua pura e absoluta ne cessidade de formas abstratas. A arte, porém, não podia abstinar sf nesse divorcio do mundo real sem arriscay-se a abdicar de sua propria condição transfor madora. A relaçāo entre o artis-

ta e o espectador - esse elemento funcional da obra de arte que tão significativa hierarquia retoma no realismo dinamico - seria possivel, por exemplo, mediante o extremismo da avasão cubista?

L.c.vado a meditar sobre estes lémas como teórico e pintor, André Lothe apregoou o retôrno ao bomem " reclamando violentamente um fumador no extremo da sempiterna pipa cubista ou braços inspirados ao redor da cbsecante guitarra insonora". Bem: este retorno ao homem é o que - diria eu, si a formula não estivesse tão desacreditada - o realismo retoma como um mandato histórico. Este realismo já nāo é, porém, um anti- 
Quase fechando o último número da revista Joaquim, o 21, de dezembro de 1948, se descreve um "realismo dinâmico", superação dialética tanto do naturalismo quanto do abstracionismo. A abstração, no panorama apresentado por Agosti, "não é, todavia, obra de arte, senão conhecimento"16, conhecimento que " [...] será obra de arte realista quando se transforme em substancia sensível." ${ }^{17}$ A revolução abstrata, ainda segundo ele, foi um "heroico ascetismo das formas" que reagiu contra o "antigo realismo antipoético", mas que abandonou "os valores éticos do conteúdo", produzindo o divórcio do mundo real e a perda da sua condição transformadora. O chamado "realismo dinâmico" aparece, assim, como "uma superação hereditária" da arte abstrata "[...] porque aproveita todos os resultados de suas excursões técnicas e os enriquece com a pompa soberba de um inflamado conteúdo humano."18 Recuperando o existencialismo já superado segundo Drummond no seu texto sobre o Invencionismo e a partir da utópica aurora, Agosti fecha o seu texto e o futuro da vanguarda do Prata, pertencente agora à galeria dos ismos do passado: "Será isto, por acaso, a proclamação de outro humanismo redentor? Talvez o seja. E talvez, também, já se esteja anunciando a resposta, com leve resplendor de aurora, entre a dura porfia dos fatos quotidianos." ${ }^{19}$

Numa tensão entre o realismo e a não-representação, assim e então, foi se constituindo a tentativa internacionalista não-provinciana da revista Joaquim. Daí que buscar estabelecer uma linha editorial clara e coerente seja um trabalho difícil e pouco frutífero: "Joaquim se fijó en un espacio estratégico que le permitió mantener cierta distancia de las ortodoxias artísticas; bastaba ser contemporáneo para ser aceptado en el sumario de la publicación", conclui María Amalia García. ${ }^{20}$ A propósito, Raúl Antelo afirmou sobre a revista literária, em geral, que ela "[...] é, a princípio, não hierárquica; ela oferece, horizontalmente, múltiplos enunciados, nem sempre passíveis de unificação ou

${ }^{16}$ AGOSTI, Héctor Pablo. "Defesa do realismo". Joaquim. Curitiba, n. 21, p. 16, dezembro de 1948.

17 Ibidem, p. 16.

18 Ibidem, p. 16.

19 Ibidem, p. 16.

${ }^{20}$ GARCÍA, María Amalia. "Vanguardia en doble página. Intervenciones del invencionismo argentino en la revista Joaquim". Revista do Instituto de Estudos Brasileiros, São Paulo, n. 61, p. 159-182, agosto de 2015. 
convergência, porém, certamente rearticuláveis, em redes aleatórias, numa leitura de conjunto realizada a posteriori. Sua multiplicidade em consequência é anômala e estriada." ${ }^{21}$ Aliás, em outro dos seus textos e lendo "Áporo", Antelo começava dizendo que "Não há caminho sem aporia", para logo depois ampliar:

A resposta [ao problema da aporia], a meu ver, encontra-se numa leitura que não veja o poema como uma forma mas como uma força. Uma força para-consistente. A força não é singular como a forma. Ela sempre se define em relação a outras forças, donde o conceito de força nos remete diretamente ao da pluralidade. [...] A força é o poder de um sujeito soberano, mas é também o objeto sobre o qual esse domínio é exercido. Portanto, uma força define-se como uma relação entre forças. Ela é uma pluralidade que sempre busca, passivamente, ser afetada por outras forças mas quer, simultaneamente, incidir ativamente sobre outras forças. Em suma, a força está sempre no meio do caminho, no entre-lugar de determinação e desejo. ${ }^{22}$

O desenho imaginado da constelação Arturo em expansão além do Prata era um conjunto de forças em aberto e, por isso, de forças informes. O primeiro anseio, até aqui, foi imaginar a possível inserção da revista Joaquim na vanguarda do Prata que desenhou a constelação Arturo. O segundo, o de localizar Carlos Drummond de Andrade dentro dessa vanguarda. Ambas tentativas resultaram difíceis pela própria complexidade da revista curitibana, porém sumamente interessantes na hora de produzir novos gestos de leitura heterocrônicos e heterotópicos dessas forças em aberto. O último passo do percurso voltará a Drummond para, enfim, nos concentrar nessa sua variante das vanguardas: o re-invencionismo.

No número 3 da revista Anhembi, de fevereiro de 1951, Drummond publica o extenso poema dramático "Os bens e o sangue" que, salvo breves modificações na pontuação e no espaçamento do poema e a presença de um prefácio que funcionava a modo de explicação do surgimento do próprio texto, apareceu depois em Claro enigma, desse mesmo ano de 1951. Mas esse breve texto inicial era fundamental para compreender melhor a potência do poema, ou algumas partes dele, enquanto ready-made:

${ }^{21}$ ANTELO, Raúl. As revistas literárias brasileiras. Boletim de pesquisa NELIC. Florianópolis, UFSC, v. 1, n. 2, p. 3, 1997.

22 Idem, A aporia da leitura. Revista Ipotesi, Juiz de Fora, v. 7, n. 1, p. 38-39, jan. / jun. 2003. 


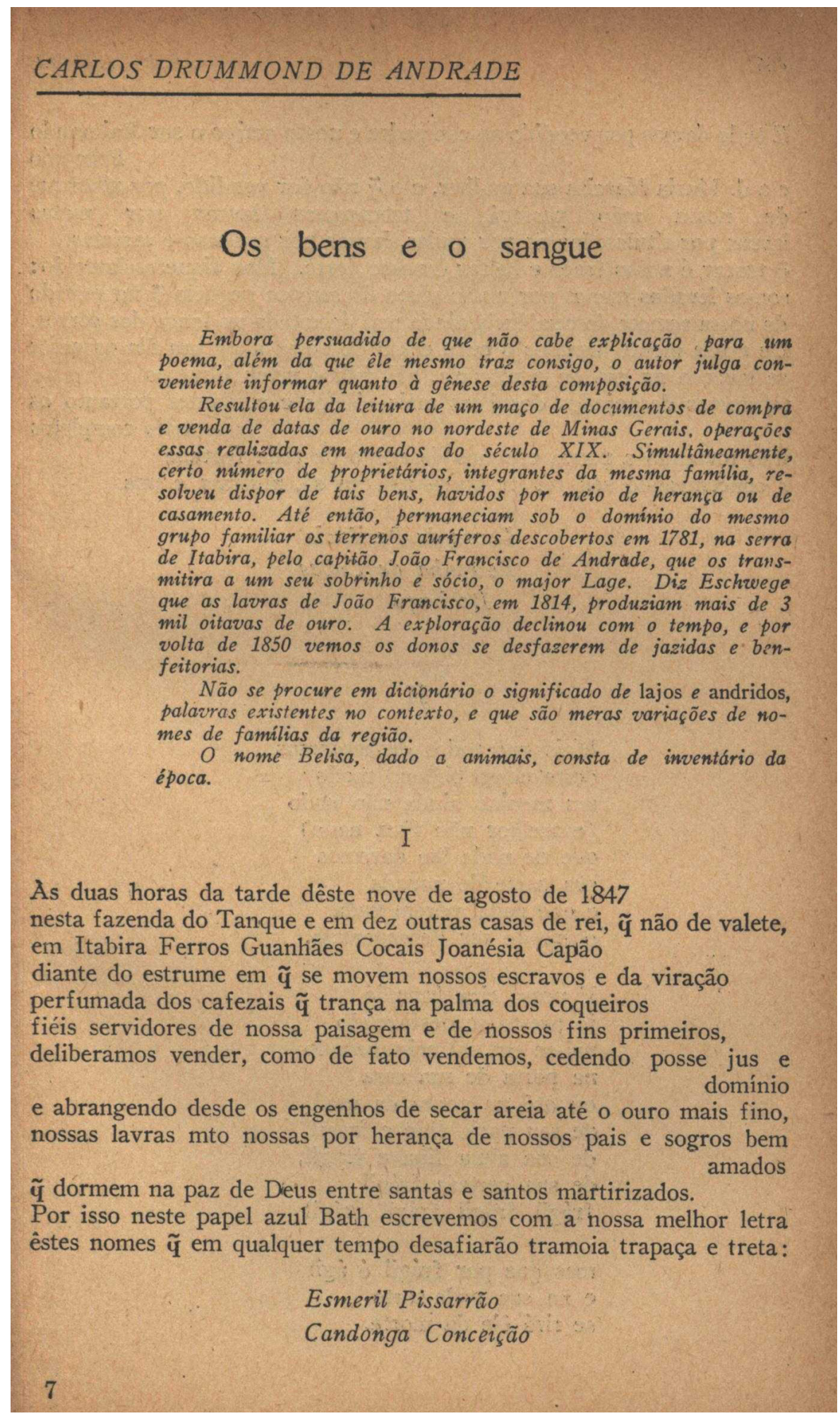

Figura 8 - "Os bens e o sangue" de Carlos Drummond de Andrade, Anhembi, São Paulo, n. 3, p. 465, fevereiro de 1951

O começo do texto esteve no encontro (e a sua posterior recuperação) de um maço de documentos de propriedade. Nesse informe sobre a gênese do 
texto do que se nos notifica é do vínculo da escritura com a propriedade, do passado com o presente, do ouro com a pobreza, da herança com o sangue, da família com o nome e o clã, do sentido das palavras com o potencial abandono da terra. Há uma coisa que passa de geração em geração, o sangue, e há outra que se perde e se converte em vestígio e gesto, os bens. Trazendo esse maço de papeis esquecidos ao espaço do poema Drummond estava propondo, mais uma vez: de modo heterocrônico e heterotópico, refletir sobre o solo espectral que serve de fundamento e adubo à poesia e que faz dela um campo de forças em tensão, em princípio, entre a vida e a morte.

A primeira parte do poema parece ter sido retirada diretamente desses documentos:

Às duas horas da tarde dêste nove de agosto de 1847

nesta fazenda do Tanque e em dez outras casas de rei, q não de valete, em Itabira Ferros Guanhães Cocais Joanésia Capão diante do estrume em q se movem nossos escravos e da viração perfumada dos cafezais $\mathbf{q}$ trança na palma dos coqueiros fiéis servidores de nossa paisagem e de nossos fins primeiros, deliberamos vender, como de fato vendemos, cedendo posse, jus e domínio e abrangendo desde os engenhos de secar areia até o ouro mais fino, nossas lavras mto nossas por herança de nossos pais e sogros bem amados q dormem na paz de Deus entre santas e santos martirizados.

Por isso neste papel azul Bath escrevemos com a nossa melhor letra êstes nomes $\mathbf{q}$ em qualquer tempo desafiarão tramoia trapaça e treta:

\title{
Esmeril Pissarrão Candonga Conceição
}

E tudo damos por vendido ao compadre e nosso amigo o snr Raimundo Procópio e a d. Maria Narcisa sua mulher, e o q não for vendido, por alborque de nossa mão passará e trocaremos lavras por matas lavras por títulos, lavras por mulas, lavras por mulatas e arriatas, q trocar é nosso fraco e lucrar é nosso forte. Mas fique esclarecido: somos levados menos por gosto do sempre negócio q no sentido de nossa remota descendência ainda mal debuxada no longe dos serros. De nossa mente lavamos o ouro como de nossa alma um dia os erros se lavarão na pia da penitência. E filhos netos bisnetos tataranetos despojados dos bens mais sólidos e rutilantes portanto os mais completos irão tomando a pouco e pouco desapêgo de tôda fortuna e concentrando seu fervor numa riqueza só, abstrata e una.

\author{
Lavra da Paciência \\ Lavrinha de Cubas \\ Itabiruçu ${ }^{23}$
}

${ }^{23}$ ANDRADE, Carlos Drummond de. Os bens e o sangue. Anhembi, São Paulo, n. 3, v.1, p. 465466, fev. 1951. Obs.: Manteve a ortografia e as marcas gráficas do original 
O poema começa sendo uma declaração da venda e troca das propriedades herdadas para deixar, enquanto nova herança, o nada material, a pobreza dos bens e o peso do futuro do passado no sangue. Esse se desprender de tudo, festivo potlatch dos antepassados, é justificado no futuro e necessário ascetismo das gerações por vir, como se nas repentinas propriedades, no ouro ou no ter existisse alguma coisa do pecado ou do Mal que impedisse uma boa e justa educação. A ruina consequência dessa venda e troca constituirá a fortuna dos deserdados, a fortuna da não fortuna, o legado de, tão só, uma "parte de nonada". A tragédia que se segue dessa venda total se desenvolve em mais sete atos-estrofes em "um tempo absurdo, ancestral e profético, futuro do passado", conforme Roberto Said ${ }^{24}$, de profundas similitudes, vale dizer, com os textos contemporâneos de Juan Rulfo. As vozes que se apropriam de cada ato são distintas como distintas são as medidas dos versos de cada uma dessas estrofes, suas grafias e sua disposição na página. O desenrolar dos versos irá observando as consequências desse se desfazer da fazenda, dessa fazenda se desfazendo em vários casos particulares, cuja maldição proferida desde o passado, atinge o presente e esboça uma galeria de desafortunadas vidas estéreis, frágeis, na franja daquilo que já não é vida e sim fundo do fundo das possibilidades do ser, vida nua.

As vozes espectrais do passado, mortos-vivos, paulatinamente, subindo da terra, vão desenhando dentre esses seres malditos a figura do poeta, marcando a sua vida entre a busca e a negação desses seus antepassados, no anseio de tentar outra forma de vida que não seja essa que as propriedades propiciariam, mesmo sendo, no final das contas, a planejada pela própria família: quer dizer, uma forma de vida que, partindo da não herança ou da herança do nada, do não, do não-nada, é des-herdada. A poesia é possível porque não se tem mais propriedades que os vestígios da venda e troca daqueles bens de família cujo registro foi achado, por acaso, num maço de documentos de cem anos atrás.

O mais deserdado foi um menino "ainda não nado", cuja única herança será uma parte de nonada. O outro terá vergonha da família e a negação será a sua marca. O seguinte será reduzido a condição de ninguém e sua única possessão será a dantesca tortura de uma violência sem movimento, desastrado e sem sorte, acaso apenas sustentado por um mel nojento, ficará aguardando os dias claros se abrirem passo na escuridão. Às três proféticas maldiçoes são seguidas de um coro de mortos que prega pelo menino e enumera as suas fu-

${ }^{24}$ SAID, Roberto. Nonada: filosofia, memória e identidade em Drummond. Aletria, Belo Horizonte, UFMG, v. 18, p. 238, jul. - dez. de 2008. 
turas desgraças e outro coro, dessa vez de urubus, que, desenrolando a história das terras após aquela primeira venda, continuaram traçando a genealogia do menino. Esse menino, por fim, será quem tome a voz na sétima estrofe, para conjurar os monstros e negar o sangue tal e como foi ou quis ser herdada. O ex-menino vira as costas e enfrenta esse rumor de ultra-túmulo que guiou a sua vida para se identificar com aqueles outros também deserdados e escolher o fio de sangue que quer seguir e alimentar dentre todos os malditos. O ex-menino, por fim, vira as costas para tentar achar, nessa escuridão de vozes, a presença do primeiro fazendeiro para pedir-lhe a benção e a proteção daqueles que não são, nonadas. Se afastando por vontade própria das propriedades alheias, o ex-menino é reconhecido enquanto poeta e consegue fazer retornar ao primeiro capitão, início do desastre. Como Juan Preciado, e a partir do achado daquele maço de documentos encenado no informe inicial e cuja maldição se estendeu ao longo de todas as estrofes do poema, fazendo dele um poema maldito e do poeta um vidente ou, talvez e também, um ouvinte que, como lemos na "Cantiga de Enganar", recebe "a partícula sonora / que a vida contém, e a morte / contém, o mero registro / da energia concentrada" 25 , ele, o próprio poeta vai ao encontro do passado para desentranhar outro futuro, entre os bens e o sangue, futuro esse então pós-histórico, onde a poesia é uma praga tóxica e letal e onde a terra nada mais é do que o solo de onde são ouvidos os mortos. "Que diz a boca do mundo?", perguntava a voz do poema a esse "meu bem" a quem estava dirigida aquela cantiga. ${ }^{26} \mathrm{~A}$ herança da des-herdança é, ao final, o prêmio desse menino, cuja pobreza é o único dom dos antepassados, mera poeira, esta e esses, que se desfaz, como àquela fazenda, no vento e, no clarão, permite ver e, depois, ouvir a boca do mundo.

O maço de documentos dá um início, verídico e legal, à montagem da genealogia maldita do poeta, num primeiro momento ligada à terra e logo mais desterrada, estabelecida entre a falta dos bens e a permanência do sangue, ambas maldiçoes que vem do futuro do passado e atingem a escrita do poema, se furtando entre várias vozes não humanas que só lembram a carência e profetizam a ruína econômica e oikonômica daquilo tudo que tome posse desse local. Re-inventado, o objeto escriturário recuperado funda uma série que já não se baseia mais nos bens senão na falta e nos vestígios daquilo que, sobrevivendo à história, ainda tem voz e se reúne no poema da praga final dos mortos-vivos ou dos vivos-mortos. Partindo dos documentos não mais

${ }^{25}$ Idem, Cantiga de Enganar. Anhembi. São Paulo, n. 9, v.3, p. 472, ago. 1951.

${ }^{26}$ Ibidem, p. 473. 
enquanto simples documentos históricos senão enquanto ready-made, objet trouvé, Drummond propõe outro começo da propriedade, da posse, da herança e da poesia. É esse o seu re-invencionismo que, surgido da notícia da descoberta -devida ao acaso- do registro passado dos mortos, mais ou menos próximo no tempo e no espaço, encena uma forma de retorno, que não será retorno do mesmo e sim retorno das possibilidades que a poeira da história foi deixando quase imperceptível nos seus vestígios. Nesses registros da morte que agora estão dispostos no espaço do poema se tece a proximidade entre repetição e memória: "Na memória, retorna o que já existiu enquanto possibilidade, ao passo que, na repetição, retorna o que não aconteceu", disse Raúl Antelo na aula inaugural do Seminário de Drummond nesse ano, "Drummond: luta, melancolia e luto". ${ }^{27} \mathrm{O}$ anseio drummondiano de escrever um livro inútil, reunindo coisas já feitas e, ao mesmo tempo, inacabadas, que aparece em Confissões de Minas, foi o que aqui chamamos re-invencionismo e que nada mais é que a forma própria do livro de areia, o gesto de desarmar a máquina do mundo para voltar a arrumá-la de outro modo.

27 ANTELO, Raúl. Drummond: luta, melancolia e luto. Aula inaugural Seminário Drummond, UFSC, 2017. 